\title{
(6) OPEN ACCESS \\ Attitudes towards cytology and human papillomavirus self-sample collection for cervical screening among Hindu women in London, UK: a mixed methods study
}

\author{
Louise Cadman, ${ }^{1}$ Lesley Ashdown-Barr, ${ }^{2}$ Jo Waller, ${ }^{3}$ Anne Szarewski ${ }^{4, \dagger}$
}

\begin{abstract}
- Additional material is published online only. To view please visit the journal online (http://dx.doi.org/10.1136/jprhc2013-100705)
\end{abstract}

For numbered affiliations see end of article.

\section{Correspondence to} Ms Louise Cadman, Centre for Cancer Prevention, Wolfson Institute of Preventive Medicine, Queen Mary University of London, Barts and The London School of Medicine and Dentistry, Charterhouse Square, London EC1M 6BQ, UK; l.cadman@qmul.ac.uk

Received 11 June 2013 Revised 4 October 2013 Accepted 5 January 2014 Published Online First 12 February 2014

\section{CrossMark}

To cite: Cadman $\mathrm{L}$, Ashdown-Barr L, Waller J, et al. I Fam Plann Reprod Health Care 2015;41:38-47.

\section{ABSTRACT \\ Objectives To explore the attitudes, views and understanding of women attending a Hindu temple in London, UK towards cervical screening, human papillomavirus (HPV) testing and two HPV self-sample collection devices: the Dacron swab and Evalyn ${ }^{\circledR}$ brush.}

Methods A mixed methods design comprising a survey and four focus groups was adopted. Focus group discussions were recorded and transcribed verbatim and explored using thematic framework analysis

Results A total of 185 Hindu women completed surveys and 23 attended focus groups. Of the respondents 75\% aged 25-64 years reported having cervical screening within the last 5 years; $85 \%$ had attended college or university. Familiar barriers to attendance for screening were identified: fear of pain and the test result, embarrassment, screener's attitude, inconvenient appointment times and difficulty with child care. Additional barriers cited included age and country of birth, with older and Indian-born women thought to be less likely to attend for screening. Self-collected sampling had a mixed reception. Women were not confident that their sample would be as good as a clinician sample and expressed concern about the impact that a positive HPV result might have on their relationships.

Conclusions Screening attendance in this highly educated group of Hindu women was slightly lower than in the general population (75\% of women aged 25-64 years had been screened in the last 5 years compared with $79 \%$ in England as a whole). Familiar barriers to screening were identified. Women felt able to collect their own sample for HPV testing with a Dacron swab but lacked confidence that it would be as good as that obtained by a clinician.

\section{Key message points}

Screening attendance in these highly educated Hindu women is less than in the general population.

- This population would currently prefer cervical smear tests as a positive human papillomavirus (HPV) test may cause relationship problems and HPV infection is untreatable.

- These women had more confidence in a doctor's sample than their own, but believe younger women would have more confidence.

\section{INTRODUCTION}

The National Health Service Cervical Screening Programme (NHSCSP) in England invites all women registered with a general practitioner (GP) aged 2549 years and 50-64 years to attend for free cervical screening, every 3 or 5 years, respectively. The stated target, to ensure that $80 \%$ of women are screened, ${ }^{1}$ has not been achieved in recent years. ${ }^{2}$ In 2011-2012 only $78.6 \%$ of women were screened at least once within the last 5 years. $^{3}$ Women aged under 50 years were less likely to attend within 3.5 years when invited $(73.5 \%)$ but more likely to have attended by 5 years $(79 \%) .{ }^{1-5}$

Inequalities in the uptake of cancer screening by ethnic minority populations have been well documented, ${ }^{6-12}$ as has the association between poor uptake and social deprivation. ${ }^{1}{ }^{13}{ }^{14}$ Education and ethnicity have been shown to be 
predictors of attendance for cervical screening, with increased likelihood of attendance among more highly educated women and white British women. ${ }^{7} 1516$

Populations are diverse and so exploring subgroups within them may provide further information regarding uptake of cervical screening. In the 2011 census, $1.5 \%$ of the population of England and Wales were recorded as Hindu (816 633). ${ }^{17}$ In addition, 58\% of Hindus in 2001 were women aged 25-64 years and likely to be eligible for cervical screening. ${ }^{18}$ Of the Hindus in England 52\% live in London, with Harrow and Brent in North West London containing the highest proportions of any of the London boroughs (20\% and $17 \%$, respectively). ${ }^{19}$

Reasons frequently given for not attending for cervical screening include the nature of the examination resulting in embarrassment and fear of pain ${ }^{20} 21$; practical issues with child care or absence from work, and concerns around the gender of the sample taker. Given the choice between a male or female GP, nonwhite women have been shown to be more likely than white women to say that they would prefer a female GP (42\% vs $29 \%){ }^{22}$

Human papillomavirus (HPV) is a common sexually transmitted virus. Persistent infection with oncogenic HPV types is associated with an increased risk of cervical cancer. ${ }^{23-25} \mathrm{HPV}$ testing therefore has a place in the field of cervical cancer prevention and, unlike cervical cytology, is proving to have great potential as a test using samples that women collect themselves and potentially in the privacy of their own home. ${ }^{26-28}$ Self-collected sample testing has been shown to have similar specificity and sensitivity to clinician sampling and is more sensitive than cytology. ${ }^{29-31} \mathrm{~A}$ test that removes some of the barriers to the uptake of cervical screening could be of benefit ${ }^{32}$ but it is important to recognise that the detection of this sexually transmitted virus may have adverse implications, particularly within some religious groups. ${ }^{33}$

It has been reported that women find self-collected sampling acceptable. ${ }^{26} 303435$ There is some evidence that women from ethnic minority groups may be willing to collect their own samples, but Indian and Pakistani women were less certain about this than white British women. ${ }^{36}$ There is scant published research regarding cervical screening uptake and women's religion. Of the Indian population in the UK approximately $45 \%$ is Hindu. ${ }^{18}$ This research group has previously explored the attitudes and understanding of Muslim women towards cervical screening, HPV testing and self-collected samples. ${ }^{37}$ Religious networks are a useful route by which health messages can be disseminated to populations where screening uptake may be low.

\section{OBJECTIVES}

To explore the attitudes and understanding of Hindu women towards cervical screening, HPV testing and self-collected HPV samples and to ascertain their views on two different self-collection devices: the Dacron swab and the Evalyn ${ }^{\circledR}$ brush.

\section{METHODS}

\section{Participants and recruitment}

Hindu women were recruited at an Open House Weekend Event in September 2011 and a Health and Vitality Day for 'Yuvati' (women aged under 40 years) in January 2012 organised by members of BAPS Shri Swaminarayan Mandir. Popularly known as the 'Neasden Temple', it is a place of worship for Hindus living in and around London and is located in the London Borough of Brent

\section{Ethical approval}

The study was approved by the UCL Research Ethics Committee.

\section{Procedure}

A mixed methods design was adopted using a survey (see online Supplementary Figure 1) and four focus group discussions (Figure 1). ${ }^{38}$ Women were approached at the above-mentioned events and were asked if they would complete a survey with the aim of gathering baseline data on screening attendance and demography. They were asked to provide contact details if they were interested in participating in focus group discussions. Of those returning the survey, 114 women consented to being contacted. A further seven were discounted as they did not indicate that they were Hindu, 31 were either too young or did not provide their age and seven provided illegible details. Those interested were subsequently contacted and invited to attend one of four focus group discussions held at the Mandir. The intention was to purposively sample if sufficient women agreed to participate. 'Snowball sampling' (i.e. using participants to recruit others) was incorporated into the recruitment process.

Women participating in the focus groups were asked to sign an informed consent form and were given $£ 20$ towards their time and travel costs. A donation was given to the BAPS Shri Swaminarayan Mandir in acknowledgement of their assistance and the facilities provided. Two researchers (JW and LC) moderated one and three focus groups, respectively. Representatives from the Mandir recommended that the groups be held in English with any translation being done within the group, as an outside translator could inhibit participants. Focus group discussions (lasting 45-60 minutes) were audio recorded and notes taken by LAB. During the discussions participants were given an information leaflet about HPV and Evalyn brush collection kits followed by Dacron swab collection kits, both with instructions. The Dacron swab resembles a cotton bud, approximately $15 \mathrm{~cm}$ long, which is inserted into the vagina and rotated for approximately 20 seconds. It is then 


\section{Article}

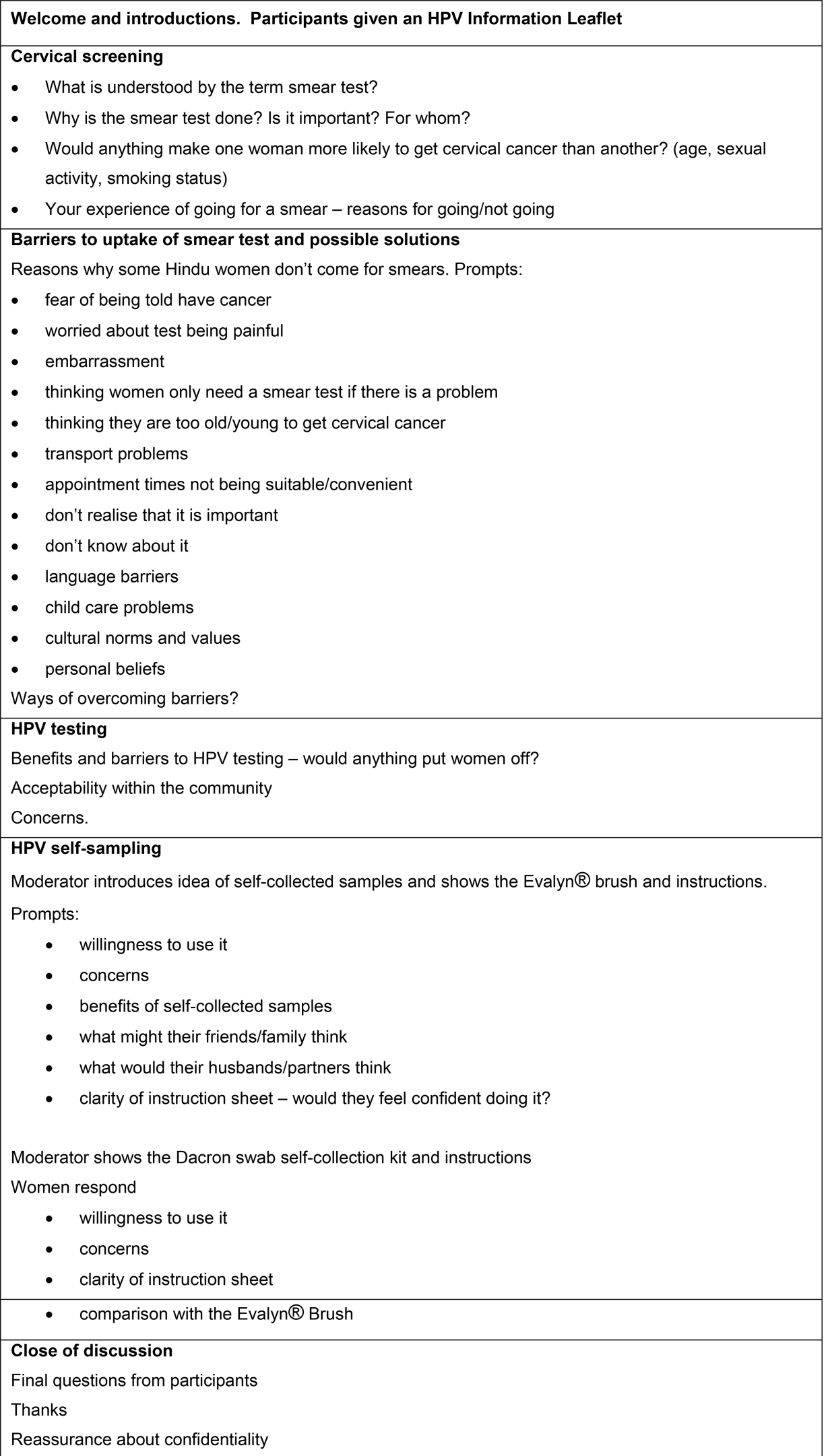

Figure 1 Topic guide for focus group discussions.

broken off into a small tube with approximately $0.5 \mathrm{ml}$ liquid specimen transport medium. The Evalyn brush consists of a pink stick with a brush at one end and a plunger at the other and is approximately $20 \mathrm{~cm}$ long. The cap is removed, the stick is inserted into the vagina, the plunger pushed to reveal the 


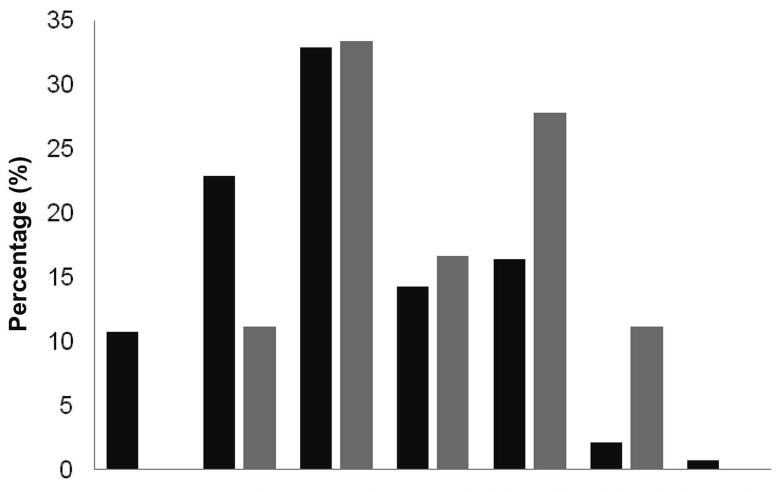

10 to 1920 to 2930 to 3940 to 4950 to 5960 to 6970 to 79 Age (years)

All Hindu women: Mean 35.8 Focus group participants: Mean 43.6 Standard deviation 12.5 Minimum 14 Maximum 70 Median 34 $\mathrm{N}=140$ Standard deviation 11.9 Minimum 23 Maximum 63 Median 42.5 $\mathrm{N}=18$

Figure 2 Age comparisons of the survey and focus groups.

brush, which is rotated five times and removed. It is then retracted into its plastic tube and the cap replaced.

\section{Analysis}

The survey data were entered onto a Microsoft Office Access 2007 database. STATA/IC 12.1 was used for statistical analysis. Initial results were tabulated and formal statistical comparisons were made using the Chi-square $\left(\chi^{2}\right)$ test and multivariate analyses using logistic regression. The focus group discussions were transcribed verbatim (LAB) and were analysed together with field notes. Recurrent themes were identified and organised into a matrix for framework analysis. ${ }^{38}$ Five main themes and twenty subthemes were identified (see online Supplementary Figure 2). Framework analysis was performed by both LC and $\mathrm{LAB}$ and any discordance was resolved by discussion.

\section{RESULTS}

\section{Sample}

Surveys were returned by 204 women (see online Supplementary Table 1) with 19 being excluded as they did not state that they were Hindu. Of the remaining 185 surveys, 45 women omitted their age, five of whom were among the 23 women who participated in focus group discussions (Figure 2) (see online Supplementary Table 1). Of those returning a survey, 114 women consented to being contacted to participate in focus group discussions, of whom 49 were discounted as they did not indicate that they were Hindu, were either too young or did not provide their age or provided illegible details. Of the remaining 65 , 18 could not be contacted or declined, leaving 31 women. This meant that purposive sampling was not realistic.

Ethnic background was described as Indian by $92 \%$ of respondents. Of those aged 25-49 years who answered the question, $64 \%$ had had cervical screening within 3 years, but this figure rose to $75 \%$ for screening within 5 years. In women aged 25-64 years, $76 \%$ reported attendance within 5 years (Table 1). The women did, however, seem to be relatively regular attenders, with $40 \%$ of women aged 50-64 years having had more than three lifetime screens (Table 2).

Only 4\% $(n=5)$ of women aged 25-64 years indicated that they did not know about cervical screening, four of whom had been in the UK for less than 6 years.

Excluding women outside the recommended screening age, when exploring attendance for screening within the recommended interval (within 3 years for women aged 25-49 years and within 5 years for women aged 50-64 years), women who were single were significantly less likely than women who were married, living with a partner, divorced, separated or widowed to have attended [OR $0.19,95 \%$ confidence interval (CI) $0.05-0.70$ ]. This result remained significant after adjusting for age (OR 0.21 , 95\% CI 0.060.83 ). Additional adjustment for educational level did not affect these results.

Screening attendance within the recommended screening interval decreased with increasing level of education, with $77 \%(n=13 / 17)$ of women not going onto further education attending compared to $56 \%$ $(n=57 / 101)$ of those who did. This, however, was not statistically significant $(p=0.12)$.

Table 1 Years since last screening by age (where given)

\begin{tabular}{|c|c|c|c|c|c|}
\hline \multirow[b]{2}{*}{ Age group (years) } & \multicolumn{5}{|c|}{ Time since last smear [n (row \%)] } \\
\hline & Never & $0-3$ years & 4-5 years & $>5$ years & Total \\
\hline$<25^{*}$ & $22(92)$ & $1(4)$ & $1(4)$ & $0(0)$ & 24 \\
\hline $25-49$ & $19(23)$ & $54(64)$ & $9(11)$ & $2(2)$ & 84 \\
\hline $50-64$ & 1 (4) & $12(48)$ & $7(28)$ & $5(20)$ & 25 \\
\hline$>64^{*}$ & $1(100)$ & $0(0)$ & $0(0)$ & $0(0)$ & 1 \\
\hline Total & $43 \quad(32)$ & $67(50)$ & $17(13)$ & $7 \quad(5)$ & 134 \\
\hline
\end{tabular}

${ }^{*}$ Not eligible for routine screening. The National Health Service Cervical Screening Programme invites women aged 25-49 years to attend for routine screening every 3 years and those aged $50-64$ years every 5 years. 
Table 2 Number of lifetime screening tests by age group

Total number of lifetime smears [ $n$ (row \%)]

\begin{tabular}{|c|c|c|c|c|c|}
\hline \multirow[b]{2}{*}{ Age group (years) } & \\
\hline & 0 & 1 & $2-3$ & $>3$ & Total \\
\hline $25-49$ & $19(23)$ & $24(29)$ & $17(20)$ & $24(29)$ & 84 \\
\hline $50-64$ & $0 \quad(0)$ & $5(20)$ & $10(40)$ & $10(40)$ & 25 \\
\hline Total & $19(17)$ & $29(27)$ & $27(25)$ & $34(31)$ & 109 \\
\hline
\end{tabular}

Pearson Chi-square $\left(\chi^{2}\right)(3)=10.03 ; p=0.18$.

Notably, $85 \%$ of respondents to the question indicated that they had attended college, university or undertaken postgraduate study (Table 3). Country of birth was statistically significant as a predictor of attendance for screening $(p=0.024)$, with women being born other than in England or India more likely to attend within the recommended screening intervals. Parity was also significant as a predictor of attendance $(p=0.037)$. Never having had sexual intercourse, not knowing about cervical screening and not considering it important, although statistically significant as predictors of attendance, were too few to be considered reliable.

Some $21 \%$ of Hindu women returning surveys indicated they were afraid of pain, $17 \%$ were embarrassed and $8 \%$ were fearful that they would be told they had cancer.

\section{QUALITATIVE RESULTS}

\section{Understanding of cervical smear test}

Although there was some confusion about whether cervical screening was also to "check the womb; and ovaries" [Participant 90 (P90)], overall women in the focus groups showed a good understanding of the purpose of the test. Some of the participants were clear that it was "to see if there's any abnormal cells" (P106) to detect whether one had a chance of getting cancer and to increase the chances of being able to treat this in the earlier stages. Some described the screening programme as for women "maybe married, unmarried if they are having a relationship" (P202). There was an acknowledgement of the association with sexual activity and that sex outside marriage may occur.

\section{Barriers to attendance for cervical screening}

Familiar barriers to attendance were confirmed by the focus group discussions: inconvenient appointment times, difficulty with child care, fear of pain, embarrassment, the sample taker may be male, the sample taker's attitude "they get angry and then you become more tense" (P90) and "some people don't go because of the frightening news they might get" (P105).

Further barriers to attendance identified within the focus group discussions were age and country of birth: "a lot of the older generation, the ones that are not well educated, don't bother" (P134). Participants said that in the case of their mothers: "They're brought up in India, they hardly take orthodox medicines or hospitals and clinics ... no awareness about their health, I'm sure they were not even educated they didn't go to schools ... so nobody told them about all this" (P90). Also "that generation felt that ... if they die it is just destiny" (P103).

\section{HPV awareness}

Some women knew of HPV because of the vaccine and associated news stories: "there was a girl who had that kind of vaccine and she was in a coma" (P106). Some were aware that the vaccine was prophylactic and had to be given to young girls "because they are not in a relationship" (P202). There was limited discussion around HPV and cervical cancer, with one participant saying "No, no, no; HPV is not related to cancer" (P197) and another that it must be transmitted "from the partner probably" (P202).

\section{Acceptability of HPV self-collected sample testing}

Self-collection or clinician sample preference

Women were positive about the HPV self-collected sampling but comments were weighted towards preferring to have a test done at their doctor's surgery: "It [HPV self-collected sample] saves you going, saves you embarrassment ... if you haven't got time to go ... I would rather do it at the doctor" (P202). Their concerns stemmed from lack of confidence that they had done the test correctly: "prefer doctor's test because they are perfect and we are not perfect" (P204). An increased screening interval if HPV testing was adopted did not have any significant appeal: "it's not worth it" (P201).

Differences between generations

Regarding younger women, "I think they'll be fine they are really quite forward" (P120) but "the older generation they wouldn't know how to do it. It would be like a bit frightening for them" (P120). Also that widows "won't even bother I think ... for them they are like more in grief really at that point". They will just say "... let's ignore it we are not having sex" (P106). They felt it would be more appropriate for them to collect and return samples to the GP rather than receive them at home. One participant, however, felt strongly that "I know my daughter ... she would rather go to the GP than do this, ... she would find that really dirty having to do that herself" (P103).

Effect of an HPV-positive result

It was expressed that "If you know you are positive then it disturbs your relationship with your partner and if there is no treatment then there is no point in having it" (P197). Countering this, however, were the views expressed that "it is up to the individual ... you have got to have trust in every marriage ... not just me but my husband as well" (P134).

It was felt by some that HPV disclosure would not be such a problem for the younger generation: "they are broad minded, they are not like us ... if someone 
Attendance for screening within recommended intervals (i.e. age 25-49 years within 3 years, 50-64 years within 5 years) [n (row \%)]

\section{Total aged 25-64 years}

Ever had an abnormal smear result

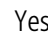

No

Parous

Yes

No

$21(26)$

$13(50)$

Country of birth

$\begin{array}{lr}\text { UK } & 9(38) \\ \text { India } & 15(40) \\ \text { Other } & 7(28)\end{array}$

Years lived in the UK

$<6$

$7-20$

$>20$

Stage at which education was completed

No response

Before secondary school

Secondary school

College or university

Postgraduate

Reasons for not going for a smear test

Does not know about smear tests

$\begin{array}{lr}\text { No response } & 32(31) \\ \text { Yes } & 4(80)\end{array}$

Embarrassment

No response

Yes

$30(33)$

Fear of cancer

$\begin{array}{lr}\text { No response } & 32(33) \\ \text { Yes } & 4(36)\end{array}$

72 (69)

1 (20)

$3(50)$

$11(85)$

$39(66)$

$18(62)$

$2(60)$

11 (65)

$50 \quad(69)$

9 (74)

3 (50)

$5 \quad(63)$

23 (61)

8 (72)

$p=0.024$

ear or pain

$\begin{array}{lr}\text { No response } & 27(30) \\ \text { Yes } & 9(47)\end{array}$

No problems in that area that need checking

$\begin{array}{lr}\text { No response } & 31(31) \\ \text { Yes } & 5(63)\end{array}$

Total

109

4

83

$p=0.19$

$p=0.037$

24

38
20

17

72

$p=0.71$

6

6
2
13
59
29
$p=0.42$

$p=0.42$

61 (67)

$12(67)$

104

5

$p=0.022$

$$
\begin{array}{r}
91 \\
18 \\
p=0.97
\end{array}
$$

$66 \quad(67)$

7 (67)

98

11

$p=0.80$

$\begin{array}{ll}63 & (70) \\ 10 & (53)\end{array}$

90

19

$p=0.14$

101

$70 \quad$ (69)

3 (38) 


\begin{tabular}{|c|c|c|c|}
\hline \multirow[b]{2}{*}{ Total aged $25-64$ years } & \multicolumn{3}{|c|}{$\begin{array}{l}\text { Attendance for screening within recommended intervals (i.e. age } 25-49 \text { years within } \\
3 \text { years, 50-64 years within } 5 \text { years) [n (row \%)] }\end{array}$} \\
\hline & $\begin{array}{l}\text { Not attended } \\
36(33)\end{array}$ & $\begin{array}{l}\text { Attended } \\
73(67)\end{array}$ & $\begin{array}{l}\text { Total } \\
109\end{array}$ \\
\hline \multicolumn{4}{|c|}{ Appointment times are not suitable/convenient } \\
\hline No response & $31 \quad(31)$ & $70 \quad(69)$ & 101 \\
\hline \multirow[t]{2}{*}{ Yes } & $5(63)$ & $3(38)$ & 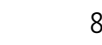 \\
\hline & & & $p=0.006$ \\
\hline \multicolumn{4}{|l|}{ Not important } \\
\hline No response & $32(31)$ & 72 (69) & 104 \\
\hline \multirow[t]{2}{*}{ Yes } & $4(80)$ & $1(20)$ & 5 \\
\hline & & & $p=0.022$ \\
\hline \multicolumn{4}{|c|}{ Information is too complicated } \\
\hline No response & $36 \quad(33)$ & $72(67)$ & 108 \\
\hline Yes & $0 \quad(0)$ & $1(100)$ & \\
\hline \multirow{2}{*}{\multicolumn{4}{|c|}{ Problems arranging child care }} \\
\hline & & & \\
\hline No response & $31(31)$ & $69(69)$ & 100 \\
\hline Yes & $5(56)$ & 4 (44) & 9 \\
\hline & & & $p=0.13$ \\
\hline \multicolumn{4}{|c|}{ Does not know anyone who goes for smear tests } \\
\hline No response & $34 \quad(32)$ & $73(68)$ & 107 \\
\hline \multirow[t]{2}{*}{ Yes } & $2(100)$ & $0 \quad(0)$ & 2 \\
\hline & & & $p=0.42$ \\
\hline \multicolumn{4}{|l|}{ Never had sexual intercourse } \\
\hline No response & $29(29)$ & $72(71)$ & 101 \\
\hline \multirow[t]{2}{*}{ Yes } & 7 (88) & 1 (13) & 8 \\
\hline & & & $p=0.001$ \\
\hline \multicolumn{4}{|c|}{ Previous surgery and does not need a smear test } \\
\hline False & $35(32)$ & $73(68)$ & 108 \\
\hline \multirow[t]{2}{*}{ True } & $1(100)$ & $0 \quad(0)$ & \\
\hline & & & $p=0.15$ \\
\hline \multicolumn{4}{|c|}{ Always go for smear tests when invited } \\
\hline False & $32(41)$ & $46 \quad(59)$ & 78 \\
\hline True & 4 (13) & 27 (87) & 31 \\
\hline
\end{tabular}

knows or not they don't worry" (P196); "in our generation you never expect that your partner will be liaising with somebody else" (P197).

With regard to the wider family: "it's up to them to sort it out. ... it is up to them I can't get involved in that" (P202). However, some women felt "the same thing is with the children also ... because you have lost the trust" (P197).

Women commented that they would find a positive result "frightening" and that "they shouldn't ... come out with a letter to say you've got this virus. They can say go to your GP” (P103).

\section{Acceptability of the HPV self-collection devices and the instruction sheets}

Women felt able to use the Dacron swab and instructions despite some concerns that "it did break easily"
(P90) and it could be lost inside them. Overall it was considered "much easier; everyone can do it, even older generation women they don't know how to read or write even so even they can do it" (P120). The Evalyn brush, however, was not so well received: "this one is too big and painful [Evalyn brush]; this one [Dacron swab] is small, this one is good, easier" (P204) and it was a "bit complicated, isn't it?; there is so many things we have to do" (P87).

\section{DISCUSSION}

This is the first study looking specifically at Hindu women in England and attendance for cervical screening. Hindus in the UK are moderately diverse in terms of deprivation with $7 \%$ living in the lowest decile of housing deprivation areas and $7 \%$ in the most advantaged decile. ${ }^{39}$ The participants in this small study 
represent well-educated Hindu women with an aboveaverage education profile. Only $15 \%$ had not continued onto further education at a college or university compared with $39 \%$ of the Hindu population of England and Wales. ${ }^{18}$ The evidence from this study, however, does not support the hypothesis that a welleducated cohort would be more likely to attend for cervical screening than the general population, with a 5 -year attendance rate for cervical screening of $75 \%$ vs $78.6 \%$ in the general population. This, may, however, simply be a fact of being Hindu rather than educational level.

Barriers to screening attendance were similar to those of other populations. It was suggested that the older generation of Hindu women (mothers and mothers-in-law) would be less likely to attend for screening or to collect a sample themselves, especially if they were born in India where there may have been less exposure to health care or education. This view on cervical screening attendance was not, however, totally borne out in this study. Within this group of women, $76 \%$ of those aged 50-64 years reported having had cervical screening within the last 5 years, and attendance for screening in accordance with recommended screening intervals was similar in women born in India and the UK (61\% vs 63\%).

With regard to self-collected samples for HPV testing, women accepted the Dacron swab collection device and instructions but were all unenthusiastic about the Evalyn brush, believing that not only was it big but they did not think that they would be able to use it. They were positive towards self-collected sampling but still expressed a preference to attend for testing at their GP surgery as they would have more confidence in the reliability of their GP's sample than their own. They were also reluctant to receive a positive HPV result, due to it being a sexually transmitted infection that could not be treated, and the impact this might have on the trust within their relationships.

\section{Limitations}

The quantitative part of the study involved a relatively small sample size, further reduced by a number of incomplete surveys. In addition, for simplicity, women were asked about their screening attendance within the last 3 years, whereas the NHSCSP reports coverage within the last 3.5 years, so the figures are not strictly comparable. In addition, women were recruited at health-related events, which might mean they were more engaged with health issues than the wider Hindu population in London.

There are limitations associated with holding focus group discussions within community groups. There may be concerns within the group around confidentiality despite clearly stated ground rules. Pragmatism meant that this was the most practical approach however.

It is recognised that by participating in research around cervical screening there may be a bias towards women who have attended for cervical screening and so the women are not necessarily representative of the Hindu population as a whole. There would be further self-selection by those women agreeing to participate in focus group discussions. This population in particular may not be representative of all Hindus in the UK.

\section{CONCLUSIONS}

It is hard to extrapolate the evidence gathered in this study to the Hindu population of England as a whole because it is a diverse population whereas this study population seems less so. However, the message these women are communicating is similar to that of other communities (e.g. Muslim ${ }^{37}$ ). They prefer to attend for cervical screening performed by a female professional than collect a sample themselves. Therefore, before self-sampling could be introduced on a larger scale efforts would need to be made to build the confidence of women regarding the quality of the sample they could collect and to address anxieties surrounding being told that they had an untreatable sexually transmitted infection. With regard to collection devices, as shown in previous research by this group, women find the Dacron swab the most acceptable device.

It would be useful to explore these issues further in harder-to-reach Hindu groups including those from less-educated backgrounds or those who do not attend for cervical screening. It would also be useful to explore methods of disseminating information around HPV and cervical cancer prevention within Hindu religious organisations and groups.

\section{Author affiliations}

${ }^{1}$ Research Nurse Consultant, Centre for Cancer Prevention, Wolfson Institute of Preventive Medicine, Queen Mary University of London, Barts and The London School of Medicine and Dentistry, London, UK

${ }^{2}$ Research Nurse, Centre for Cancer Prevention, Wolfson Institute of Preventive Medicine, Queen Mary University of London, Barts and The London School of Medicine and Dentistry, London, UK

${ }^{3}$ Senior Research Associate, Department of Epidemiology and Public Health, Cancer Research UK Health Behaviour Research Centre, University College London, London, UK

${ }^{4}$ Clinical Senior Lecturer, Centre for Cancer Prevention, Wolfson Institute of Preventive Medicine, Queen Mary University of London, Barts and The London School of Medicine and Dentistry, London, UK

${ }^{\dagger}$ Deceased. 
Acknowledgements The authors thank Dr Sejal Saglani and the women who took part in this research and representatives from the BAPS Shri Swaminarayan Mandir.

Funding This study was funded by an Investigator Initiated Study Grant from Bayer AG. The study was also supported by Cancer Research UK Programme Grants (C569/A10404 and C8162/A10406).

\section{Competing interests None.}

Ethics approval UCL Research Ethics Committee.

Provenance and peer review Not commissioned; externally peer reviewed.

Open Access This is an Open Access article distributed in accordance with the Creative Commons Attribution Non Commercial (CC BY-NC 3.0) license, which permits others to distribute, remix, adapt, build upon this work noncommercially, and license their derivative works on different terms, provided the original work is properly cited and the use is non-commercial. See: http://creativecommons.org/licenses/by$\mathrm{nc} / 3.0 /$

\section{REFERENCES}

1 Baker D, Middleton E. Cervical screening and health inequality in England in the 1990s. J Epidemiol Community Health 2003;57:417-423.

2 NHS Cervical Screening 2008 Annual Review NHS Cervical Screening Programme, 2008. http://www.cancerscreening.nhs. uk/cervical/publications/2008review.html [accessed 3 Oct 2013].

3 NHS Cervical Screening 2012 Annual Review NHS Cervical Screening Programme, Programme CS, 2012. http://www. cancerscreening.nhs.uk/cervical/publications/2012review.html [accessed 3 Oct 2013].

4 Willoughby BJ, Faulkner K, Stamp EC, et al. A descriptive study of the decline in cervical screening coverage rates in the North East and Yorkshire and the Humber regions of the UK from 1995 to 2005. J Public Health (Oxf) 2006;28: 355-360.

5 Lancuck L, Patnick J, Vessey M. A cohort effect in cervical screening coverage? J Med Screen 2008;15:27-29.

6 Luke K. Cervical cancer screening: meeting the needs of minority ethnic women. Br J Cancer Suppl 1996;29: S47-S50.

7 Moser K, Patnick J, Beral V. Inequalities in reported use of breast and cervical screening in Great Britain: analysis of cross sectional survey data. BMJ 2009;338:b2025.

8 Webb R, Richardson J, Esmail A, et al. Uptake for cervical screening by ethnicity and place-of-birth: a population-based cross-sectional study. J Public Health (Oxf) 2004;26:293-296.

9 Szczepura A, Price C, Gumber A. Breast and bowel cancer screening uptake patterns over 15 years for UK south Asian ethnic minority populations, corrected for differences in socio-demographic characteristics. BMC Public Health 2008;8:346.

10 Norredam M, Nielsen SS, Krasnik A. Migrants' utilization of somatic healthcare services in Europe - a systematic review. Eur J Public Health 2009;20:555-563.

11 Price CL, Szczepura AK, Gumber AK, et al. Comparison of breast and bowel cancer screening uptake patterns in a common cohort of South Asian women in England. BMC Health Serv Res 2010;10:103.

12 Robb KA, Power E, Atkin W, et al. Ethnic differences in participation in flexible sigmoidoscopy screening in the UK. J Med Screen 2008;15:130-136.
13 Bang JY, Yadegarfar G, Soljak M, et al. Primary care factors associated with cervical screening coverage in England. J Public Health (Oxf) 2012;34:532-538.

14 Bansal N, Bhopal RS, Steiner MF, et al. Major ethnic group differences in breast cancer screening uptake in Scotland are not extinguished by adjustment for indices of geographical residence, area deprivation, long-term illness and education. Br J Cancer 2012;106:1361-1366.

15 Sutton S, Rutherford C. Sociodemographic and attitudinal correlates of cervical screening uptake in a national sample of women in Britain. Soc Sci Med 2005;61:2460-2465.

16 Sabates R, Feinstein L. The role of education in the uptake of preventative health care: the case of cervical screening in Britain. Soc Sci Med 2006;62:2998-3010.

17 Office for National Statistics. 2011 Census: Key Statistics for England and Wales, March 2011, 2012.

18 Census 2001 National Report for England and Wales National Report for England and Wales: All People Part 1 (Table S103). 2004. http://www.ons.gov.uk/ons/search/index. html content-type $=$ Reference + table\&pubdateRangeType $=$ allDates\&newquery $=$ Census $+2001+$ National + Report + for +England+and+Wales+-+National+Report+for+England + and + Wales $\% 3 \mathrm{~A}+$ All + people + Part $+1+\% 28$ Table + S103\% 29\&pageSize $=50$ \&applyFilters $=$ true $[$ accessed 3 October 2013].

19 Dobbs JGH, Zealey L. Focus on Ethnicity and Religion. London, UK: Office for National Statistics, 2006.

20 Ackerson K, Preston SD. A decision theory perspective on why women do or do not decide to have cancer screening: systematic review. J Adv Nurs 2009;65:1130-1140.

21 Robb KA, Solarin I, Power E, et al. Attitudes to colorectal cancer screening among ethnic minority groups in the UK. BMC Public Health 2008;8:34.

22 Populus Poll of Women: Populus, 2008. http://www. cancerscreening.nhs.uk/cervical/POPULUS-BME-POLL.pdf [accessed 3 Oct 2013].

23 Bosch FX, Castellsague X, de Sanjose S. HPV and cervical cancer: screening or vaccination? Br J Cancer 2008;98:15-21.

24 Koliopoulos G, Arbyn M, Martin-Hirsch P, et al. Diagnostic accuracy of human papillomavirus testing in primary cervical screening: a systematic review and meta-analysis of nonrandomized studies. Gynecol Oncol 2007;104:232-246.

25 Walboomers JM, Jacobs MV, Manos MM, et al. Human papillomavirus is a necessary cause of invasive cervical cancer worldwide. J Pathol 1999;189:12-19.

26 Bais AG, van Kemenade FJ, Berkhof J, et al. Human papillomavirus testing on self-sampled cervicovaginal brushes: an effective alternative to protect nonresponders in cervical screening programs. Int J Cancer 2007;120:1505-1510.

27 Gok M, Heideman DA, van Kemenade FJ, et al. Offering self-sampling for human papillomavirus testing to nonattendees of the cervical screening programme: characteristics of the responders. Eur J Cancer 2011;48:1799-1808.

28 Waller J, Bartoszek M, Marlow L, et al. Barriers to cervical cancer screening attendance in England: a population-based survey. J Med Screen 2009;16:199-204.

29 Ogilvie GS, Patrick DM, Schulzer M, et al. Diagnostic accuracy of self collected vaginal specimens for human papillomavirus compared to clinician collected human papillomavirus specimens: a meta-analysis. Sex Transm Infect $2005 ; 81: 207-212$. 
30 Szarewski A, Cadman L, Mallett S, et al. Human papillomavirus testing by self-sampling: assessment of accuracy in an unsupervised clinical setting. J Med Screen 2007;14:34-42.

31 Petignat P, Faltin DL, Bruchim I, et al. Are self-collected samples comparable to physician-collected cervical specimens for human papillomavirus DNA testing? A systematic review and meta-analysis. Gynecol Oncol 2007;105:530-535.

32 Waller J, Jackowska M, Marlow L, et al. Exploring age differences in reasons for nonattendance for cervical screening: a qualitative study. BJOG 2012;119:26-32.

33 McCaffery K, Forrest S, Waller J, et al. Attitudes towards HPV testing: a qualitative study of beliefs among Indian, Pakistani, African-Caribbean and white British women in the UK. $\mathrm{Br} J$ Cancer 2003;88:42-46.

34 Barata PC, Mai V, Howlett R, et al. Discussions about self-obtained samples for HPV testing as an alternative for cervical cancer prevention. J Psychosom Obstet Gynecol 2008;29:251-257.
35 Waller J, McCaffery K, Forrest S, et al. Acceptability of unsupervised HPV self-sampling using written instructions. J Med Screen 2006;13:208-213.

36 Forrest S, McCaffery K, Waller J, et al. Attitudes to self-sampling for HPV among Indian, Pakistani, African-Caribbean and white British women in Manchester, UK. J Med Screen 2004;11:85-88.

37 Szarewski A, Cadman L, Ashdown-Barr L, et al. Exploring the acceptability of two self-sampling devices for human papillomavirus testing in the cervical screening context: a qualitative study of Muslim women in London. J Med Screen 2009;16:193-198.

38 Ritchie J, Lewis J (eds). Qualitative Research Practice: A Guide for Social Science Students and Researchers. Thousand Oaks, CA: Sage, 2003;38-46.

39 Office of the Deputy Prime Minister. Review of the Evidence Base on Faith Communities. London, UK: HMSO; 2006.

\section{Journal of Family Planning and Reproductive Health Care}

\section{Anne Szarewski Journal Memorial Award}

The Journal of Family Planning and Reproductive Health Care has established an award to commemorate the life of Anne Szarewski, our Editor-in-Chief for 10 years until her untimely death in August 2013. Anne was an inspiring journal editor, a great sexual and reproductive healthcare doctor and a pioneering researcher in the prevention of cervical cancer.

Entries for the award should take the form of a single-author article, suitable for publication in the Journal, on new initiatives or improvements in clinical practice. The author may be a nurse or midwife, a general practitioner, or a specialty trainee in sexual and reproductive healthcare or genitourinary medicine.

The award will be made annually for a period of 5 years from June 2015. In addition to publication of the winning article in the Journal, the winner will be offered the opportunity to present their work at one of the FSRH conferences during the year following the award, and will receive complimentary registration for that conference.

Full details of the award can be found on the Journal (jfprhc.bmj.com) and Faculty (www.fsrh.org) websites. 